\title{
Assessment of the Instructional Competence of College Science Teachers in a Selected University
}

\author{
Maria Hedley A. Basco* \\ Associate Professor, School of Science and Technology, Centro Escolar University, Manila, Philippines \\ *Corresponding Author: Maria Hedley A. Basco, Associate Professor, School of Science and \\ Technology, Centro Escolar University, Manila, Philippines
}

\begin{abstract}
The main objective of this study was to assess the instructional competence of College Science Teachers in three campuses of a selected University based on the perception of the school's administrators and students. The result of which will serve as a basis for a proposed instructional module for College Teachers. Descriptive-comparative research was used as the design of the study with the use of questionnaires as means for data collection. In addition, purposive sampling technique was used to determine the respondents of the study. Results showed that college science teachers are competent in the following domains, namely: learning environment, diversity of learners, curriculum, and social regard for learning. A significant difference was noted in the evaluation of administrators and the students. Therefore, there is a need to proposed an instructional module for College Science Teachers.
\end{abstract}

Keywords: Assessment, Instructional Competencies, College Science Teacher

\section{INTRODUCTION}

The problem on the poor quality of students has been accounted for several factors. One of them is the lack of competencies and skills of teachers due to the finding that most Filipino teachers do not manifest adequate knowledge in teaching math and science subjects. Also, the deterioration on the status of education in the Philippines, especially in the field of Mathematics, Science and English is blamed on teachers.

The teachers must know what to teach and how to teach because their qualifications are essential for effective teaching and better-learning process. These things should be considered because teacher's capacity to teach affects the students' performance.

It has been observed that science teaching in the Philippines focuses discussion more on the content rather than in-depth discussion of the principles and concepts. This is evident in the depressing scores of our students' performance in Mathematics and Science categories in the International Association for the Evaluation of Educational Achievement.

As scientific information grows, it seems almost difficult to require students to memorize facts and definitions. Any teacher hoping to help students learn about science needs some tested and proven science teaching strategies to help. Science is a very complex subject and for students to appreciate it better, they must find it interesting and challenging. For this reason, it is crucial for teachers to be equipped with effective science teaching strategies and methods that can help students learn quickly and effectively. To motivate students, science teachers must be equipped with effective communication skills, time-management skills and organizational skills. In addition, they should be able to work with diverse students, measure student progress and instruct students through hands-on activities.

In response to the national call for science teaching reform, there is a need to intensify professional development programs that address the issue on teachers becoming highly qualified in the teaching of content area. Another way is to encourage science teachers to conduct classroom research directed toward much improved academic performance of their studies. There are also economic benefits to the schools and to society at large in having science teachers take part in research experiences. 
These are the realities that prompted the researcher to assess the administrators' and students' perceptions on the instructional competence of college science teachers using the eight domains in the Laboratory Instructor Behavior Inventory (LIBI).

\section{Materials AND Method}

\subsection{Research Design}

The researcher utilized the descriptive method of research in this study. In this study the comparative method will be utilized to compare the perceived instructional competence of college science teachers between the administrators and students.

\subsection{Participants}

The study utilized purposive sampling technique in determining the 441 students coming from the three campuses of the selected university and two (2) Academic Department Heads from the Biological Sciences Department and Physical Sciences Department. The participants evaluated 63 Physical Sciences teachers handling chemistry and physics subjects and all Biological Sciences teachers handling Biology, Botany and Zoology.

\subsection{Instruments of the Study}

Preliminary items regarding the profile of the college science teachers' age, gender, civil status and highest educational attainment, field of specialization and years of teaching experience were obtained from the college science teachers' file information of their respective departments.

In assessing the instructional competence of the college science teachers, the researcher utilized the Laboratory Instructor Behavior Inventory (LIBI) of the university since it covered a wider scope of instructional competence applicable to both lecture and laboratory science teachers. It consists of four domains of instructional competence, namely, (1) learning environment, (2) diversity of learners, (3) curriculum and (4) assessing and reporting. In addition, there were two sets of raters for the LIBI, the administrator-respondents and the student-respondents. These two ratings covered all the college science teachers teaching in the three campuses of the university.

\subsection{Data Analysis}

Descriptive statistics were utilized to analyze the data collected such as mean and standard deviation. Furthermore, t test was used to compare the administrators' and students' perceptions on the instructional competence of college science teachers.

\section{ReSUlts}

\subsection{Instructional Competence of College Science Teachers as Assessed by the Administrators and Students'}

The results showed that the administrators perception of the college science teachers in four domains of instructional competence were rated as "always" with the learning environment having the highest mean and the assessing and reporting with the lowest mean. On the other hand, students' perception in four domains were rated as "often" with assessing and reporting having the lowest mean and learning environment with the highest mean.

Table1. Instructional Competence of College Science Teachers as Assessed by the Administrators and Students,

\begin{tabular}{|c|c|c|c|c|}
\hline Instructional Competence & \multicolumn{2}{|c|}{ Students' Perception } & \multicolumn{2}{c|}{ Administrators' Perception } \\
\hline Indicators & Over-all Mean & Interpretation & Over-all Mean & Interpretation \\
\hline Learning Environment & 4.38 & Often & 4.99 & Always \\
\hline Diversity of Learners & 4.18 & Often & 4.83 & Always \\
\hline Curriculum & 4.23 & Often & 4.94 & Always \\
\hline Assessing and Reporting & 4.16 & Often & 4.79 & Always \\
\hline
\end{tabular}

\subsection{Comparison between the Administrators' and Student's Perceived Instructional Competence of College Science Teachers}

Table2 shows show the significant difference between the administrators' and the students' perceptions on the instructional competence of college science teachers. Results revealed a very significant difference as proven by $\mathrm{p}$ values of less than 0.01 in all four domains. 
Table2. Difference between the Administrators and Student's Perceived Instructional Competencies of College Science Teachers

\begin{tabular}{|c|c|c|c|}
\hline Instructional Competence & t value & p value & Interpretation \\
\hline Learning Environment & 7.657 & $* 0.000$ & Significant \\
\hline Diversity of Learners & 6.885 & $* 0.000$ & Significant \\
\hline Curriculum & 7.768 & $* 0.000$ & Significant \\
\hline Assessing and Reporting & 6.307 & $* 0.000$ & Significant \\
\hline
\end{tabular}

*p value is significant at 0.01 level

\section{DISCUSSION}

This study aimed to determine the instructional competencies of college science teachers as perceived by administrators' and students' in a selected university and to compare the difference between their assessment. Evaluations and assessments are necessary means to establish the extent to which quality, relevance, and other educational goals are being met ${ }^{[1]}$. Results of the study indicated that students rated the instructional competence of the college science teachers as "often" with the learning environment topping the list. This domain focuses on importance of providing social, psychological and physical environment within which all students, regardless of their individual differences in learning, can engage in the different learning activities and work towards attaining high standards of learning. The findings of the study were supported by Palmer ${ }^{[2]}$ which stated that the characteristic which most students valued was the teacher's ability to encourage interaction in the class. These are the lecturers who "encouraged questions from the group", "always listened and understood questions, and responded to questions thoroughly", "directed discussion to cover the topic", "provided plenty of time for group and whole class discussion", and "allowed for student input and always prepared to listen, as well, as teach". Furthermore, Maybay-Toroy ${ }^{[3]}$ concluded in his study that a "very satisfactory" rating in Chemistry teaching in a University in Iloilo is accounted to the highly qualified teachers. On the other hand, Tagomori ${ }^{[4]}$ questioned the reliability of the instruments used by students to evaluate faculty performance. He established that the assessment used by universities and colleges to appraise a professor's teaching effectiveness were conducted by evaluation through the instruments they themselves designed, borrow, or adapt from other universities and colleges, hence, comprehensive content analysis of faculty evaluation instruments has not been conducted. As a result, faculty members in higher education may be evaluated with flawed evaluation instruments, conceivably leading to unfair assessment of their teaching performance.

Teachers' strengths must work and complement the learning needs and requirements of the entire student population. The competencies required by the standard focus on the conditions which affect student learning. These will lead teachers to develop expertise needed to enable the students to function as independent thinkers and creative learners both within the school-community and in the larger society as well. Teachers should regularly assess of their current practices to identify their individual strengths and development needs. School heads, division and regional offices should also regularly identify teacher performance factors that affect school-wide learning outcomes. This holds true for public schools and state universities. The results showed that the administrators rated the instructional competence of college science teachers as "always" in all four domains. Abiog ${ }^{[5]}$ believed that the relevance of professional competencies include the teachers' knowledge of general subject matter taught, the understanding of psychological and educational principle, and the understanding and appreciation of the teaching profession. Aguilar ${ }^{[6]}$ noted in her study that teachers who occupy administrative position have more teaching experience, and are exposed to professional growth activities are the ones perceived to be more competent in teaching. Petersonl ${ }^{[7]}$ added that the success in teaching is reflected not only on the personal qualities of the graduates but it is also shown in their performance. The ultimate criterion of teaching success is the number, kind and amount of desirable change produced in the pupils.

Overall, assessing and reporting has the lowest mean in both the students' and administrators' assessment out of the four domains of instructional competence. This domain refers to the alignment of assessment and planning activities. In particular, this domain focuses on the (1) use of assessment 
data to plan and revise teaching-learning plans; (2) integration of assessment procedures in the plan and implementation of teaching-learning activities, and (3) reporting of the learners' actual achievement and behavior. These findings were supported by Bajado [8] which revealed that teacher educators in Region VIII need some enhancement in giving of assignments, their way of asking questions so that students would think critically, upgrading their evaluation and questioning techniques and giving feedbacks to learners on their performance.

\section{CONCLUSION}

The results concluded that there is a significant difference between the students' and administrators' perceived instructional competencies of College Science teachers in the selected University, hence, a proposed instructional module should be proposed.

\section{REFERENCES}

[1] Kerrison, R. (2006). Retraining Chemistry Teachers in the Philippines. Research in Science Education. 10 (9), 248-254.

[2] Palmer, D. (1997). Students Perceptions of Their Best Teachers. Research in Science and Technological Education. 15 (2)

[3] Maybay-Toroy, J. (2006). Students; Evaluation of Chemistry Teaching: Its Relationship to their Academic Performance in General Chemistry. Master's Thesis, University of Iloilo,Iloilo.

[4] Tagamori, H. (1993). Assessment of Instruments Used For Student Evaluation of Faculty. Ed.D. Dissertation, University of San Francisco, California. 39-40.

[5] Abiog, Z. (2004). The Effects of the Deans' Human Relations Practices on Faculty Morale Commitment and Instructional Performance: Basis for Management Intervention. Ph.D. Dissertation, Trinity University of Asia, Quezon City. 48

[6] Aguilar, E. (1997). The Effects of Selected Intellective and Non-Intellective Variables on the Teaching Competencies of College Physical Education Instructions in a University Setting, Master's Thesis, Centro Escolar University, Manila. 24

[7] Peterson, K. (2000). Teacher Evaluation: A Comprehensive Guide to New Direction and Practices. 2nd ed. California: Corwin Press.

[8] Bajado, R. (2007). The Performance of Teacher Educators in Selected State Higher Education Institutions in Region VIII. Ed.D. Dissertation, Centro Escolar University, Manila. 192

Citation: Maria Hedley A. Basco. " Assessment of the Instructional Competence of College Science Teachers in a Selected University." International Journal of Humanities Social Sciences and Education (IJHSSE), vol 4, no. 10, 2017, pp. 59-62. doi:http://dx.doi.org/10.20431/2349-0381.0410008.

Copyright: () 2017 Authors. This is an open-access article distributed under the terms of the Creative Commons Attribution License, which permits unrestricted use, distribution, and reproduction in any medium, provided the original author and source are credited. 